1082

日本機械学会論文集 (B 編)

76 巻 767 号 $(2010-7)$

論文 No.09-1116

\title{
形状記憶合金エンジンの高出力化に関する研究*
}

$$
\begin{array}{lllll}
\text { 佐 藤 義 } \text { 久 }^{* 1} \text {, 吉 嶺 和 哉*2 } \\
\text { 森 本 浩 紀*2, 藤. 田 秀 紀*3 }
\end{array}
$$

\section{Study on the High Output Characteristics of the Shape Memory Alloy Engine}

\author{
Yoshihisa SATO*4, Kazuya YOSHIMINE, \\ Hiroki MORIMOTO and Hideki FUJITA
}

*4 Department of Electrical and Electronic Engineering, Daido University,
10-3 Takiharu-cho, Minami-ku, Nagoya-shi, Aichi, 457-8530 Japan

\begin{abstract}
The purpose of this research is to clarify the requirements for the high output power SMA engine. The main results obtained by this research are as follows. In order to increase the output power of the SMA engine, it is necessary to make the radius of the high temperature wheel as small as possible, while the minimum value of this radius is restricted by the distortion of the SMA belt. On one hand, the output power of the SMA engine distinctly depends on the radius of the high temperature wheel and the diameter of the SMA belt. On the other hand, it slightly depends on the radius of the low temperature wheel and the length of the SMA belt. Thus, we experimentally verified that the output power of the SMA engine distinctly depends on the radius of the high temperature wheel and the diameter of the SMA belt.
\end{abstract}

Key Words: Shape Memory Alloy, SMA Engine, Energy Conversion, Thermal Efficiency

\section{1. 緒言}

形状記憶合金(SMA : Shape Memory Alloy) は常温で 変形させても加熱すると元の形状に戻る性質がある。 SMAの形状記憶効果孝利用した単純プーリ型 SMA エ ンジンに関しては W.S.Ginell，戸伏，岩永等によって 基礎的な研究がなされている(1).(2), (3). 著者等は SMA エンジンを用いて，火力発電所から排出されるボイラ 排ガス，蒸気タービン排熱，工場排熱あるいはガス給 湯器の排熱等の未利用熱エネルギーを有効活用する研 究を行っている. 低温の未利用熱エネルギ一を有効活 用する新発電システムの開発を目標に，単純プーリー 型SMA エンジンの回転角速度 $\omega_{\max }\left[\sec ^{-1}\right]$, 出力 $P_{\max }[\mathrm{W}]$ をSMAベルトの形状・寸法, SMAベルトの高温域の ヤング率 $E_{1}$ および低温域のヤング率 $E_{2}, \mathrm{SMA}$ エンジ

* 原稿受付 2009 年 12 月 28 日.

*1 正員, 大同大学工学部 (표 457-8530 名古屋市南区潼春町 103).

*2 大同大学大学院工学研究科電気・電子工学専攻.

*3 中部電力(株) 電力技術研究所 (画 459-8522 名古屋市緑区大 高町字北関山 20-1).

E-mail : satoy@daido-it.ac.jp
ンの高温輪の半径 $r$ および低温輪の半径 $R$ のみから予 測可能な理論式を導出し，さらに大型 SMA 実験装置 を設計・製作し，SMA エンジンの回転角速度 $\omega\left[\mathrm{sec}^{-1}\right]$ とトルク $T[\mathrm{~N} \cdot \mathrm{m}]$ を同時測定することで理論の妥当性 を実験的に検証した (4), (5), (6). 本研究は提唱した理論式 を用いてシミュレーションを行うことにより，高出力 化の方向性を見定め，その妥当性を実験的に検証する ことを目的としている. SMA エンジンは数 $10^{\circ} \mathrm{C}$ 数 $100^{\circ} \mathrm{C}$ 温度範用の排熱に適用可能であるが, 一般的な $\mathrm{Ti}-\mathrm{Ni}$ 成分の形状記憶合金の変態温度が $100^{\circ} \mathrm{C}$ 程度であ ること， $200^{\circ} \mathrm{C}$ 以上の温度領域で江熱電素子， $400^{\circ} \mathrm{CW}$ 上では通常の蔒気タービン発電も可能であることより， 本論文で詨象とする温度領域は $100^{\circ} \mathrm{C}$ 程度以下の比較 的低温の未利用熱エネルギーと考えている，本装置の 適用例として 100 万 $\mathrm{kW}$ 火力発電所のタービン排熱を 想定すると, SMA エンジンの入り口温度(高温輪の温 度)は $100^{\circ} \mathrm{C}$ 以下, 出口温度(低温輪の自然空冷温度)は $40^{\circ} \mathrm{C}$ 程度であるから，実用的な熱効率は数\%程度と考 えられる. したがって，本論文で対象とする SMA エ ンジンの装置规模は出力 5 万 $\mathrm{kW}$ 以下を想定している. 


\section{2. 主な記号}

\begin{tabular}{|c|c|}
\hline$R$ & : 低温輪の半径 $[\mathrm{cm}]$ \\
\hline$r$ & : 高温輪の半径 [cm] \\
\hline$d$ & : SMA ベルトの直径[mm] \\
\hline$E_{1}$ & : SMA ベルトの高温域のヤング率 $[\mathrm{GPa}]$ \\
\hline$E_{2}$ & : SMA ベルトの低温域のヤング率[GPa] \\
\hline$M$ & : SMA ベルトの曲げモーメント $[\mathrm{N} ・ \mathrm{~m}]$ \\
\hline$M_{\mathrm{h}}$ & : 高温輪の回転モーメント[N・m] \\
\hline$t$ & : SMA ベルトの温度[C] \\
\hline$\omega_{1}$ & : 高温輪の回転角速度 $\left[\sec ^{-1}\right]$ \\
\hline$\omega$ & : 低温輪の回転角速度 $\left[\mathrm{sec}^{-1}\right]$ \\
\hline$P$ & : SMA エンジンの出力[W] \\
\hline$J_{1}$ & : 高温輪の慣性モーメント $\left.\mathrm{kg} \cdot \mathrm{m}^{2}\right]$ \\
\hline$J_{2}$ & : 低温輪の慣性モーメント $\left[\mathrm{kg} \cdot \mathrm{m}^{2}\right]$ \\
\hline$L$ & : SMA ベルトの長さ[m] \\
\hline$T$ & : 出力輪(低温輪)のトルク $[\mathrm{N} \cdot \mathrm{m}]$ \\
\hline$n$ & : SMA ベルトの周回数 \\
\hline
\end{tabular}

MPP : Maximum Power Point (最大出力点)
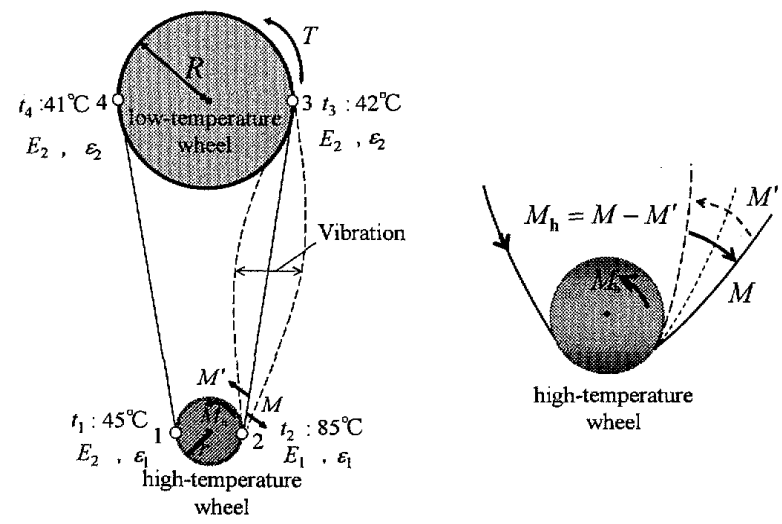

Fig. 1 The symbols of experiment equipment

\section{3. 研究の背最 - 目的}

SMA ベルトは図 1 に示すように, 点 1 で高温輪に接 して曲げられ(ひずみ $\varepsilon_{1}$, ヤング率 $\left.E_{2}\right)$ ，お湯に浸かり加 熱されながら回転し, 点 2 で変態温度に達しひずみと, ヤング率 $E_{1}$ ), 真っ直ぐにならうとし, 曲げモーメント $M$ を発生する. その後, SMA ゙゙ルトは引き戻され, 曲 げモーメント $M^{\prime}$ を発生させる. この曲げモーメント の差 $M-M^{\prime}$ が SMA エンジンの回転モーメント $M_{\mathrm{h}}$ と なる.これを繰り返し, SMA ベルトは振動しながら回 転し続けるのではないかと考え, 我々は SMA エンジ ンの無負荷時の最大回転角速度 $\omega_{\max }\left[\mathrm{sec}^{-1}\right]$, および最大 出力 $P_{\max }[\mathrm{W}]$ を予測する理論式を SMA エンジンの外形 的な諸量 $\left(d, r, R, L, J_{1}, J_{2}, E_{1}, E_{2}\right)$ のみから導いた (4), (5), (9). 本研究の目的は導出した理論式に基づくシミ
ユレーションを行い, SMA エンジンの高出力化の方向 性を明らかにすると共に, シミュレーションで明らか にした高出力化条件を反映させた実験装置を用いて SMA ベルトの直径 $d$ を変化させた場合の回転角速度 $\omega_{\max }$, 出力 $P_{\max }$ の実験值を求め, シミュレーションよ り求めた $\omega_{\max }-d$ 曲線および $P_{\text {max }}-d$ 曲線と比較検討す ることにより, 高出力化の方向性の妥当性を実験的に 検証することである.

\section{SMA エンジンの高出カ化}

4.1 高出力化の方向性 我々は前報までに SMA エンジンの最大回転角速度 $\omega_{\max }\left[\mathrm{sec}^{-1}\right]$, 最大出力 $P_{\max }[\mathrm{W}]$ を次式のとおり導出した。

$$
\omega_{\max }=\left(\frac{n \pi d^{4} L r^{2}\left(\frac{E_{1}-E_{2}}{r^{2}}-\frac{2 E_{2}}{R^{2}}\right)}{64\left(J_{1} R^{2}+J_{2} r^{2}\right)}\right)^{\frac{1}{2}}\left[\sec ^{-1}\right], n=2,3
$$

$P_{\max }=\frac{\omega_{\max }}{2} \cdot \frac{\pi d^{4} R\left(E_{1}-E_{2}\right)}{128 r^{2}}[\mathrm{~W}]$

SMA エンジンを高出力化する為には，式(1)，(2)を 詳細に検討することにより，以下の方向性がかかる.

(1)SMA ベルトの直径 $d$ を太くする.

(2)高温輪の半径 $r$ を小さする.

(3)低温輪の半径 $R$ を大きくする.

(4)SMA ベルトの長さ $L$ を長くする.

(5)慣性モーメント $J_{1}, J_{2}$ を小さくする.

(車輪を肉抜きする等軽くする)

(6)ヤング率の差 $E_{1}-E_{2}$ を大きくする.

$\left(E_{1} \rightarrow\right.$ 大きく, $E_{2} \rightarrow$ 小さく $)$

上記(1) (6)の方法で SMA エンジンの外形諸量 $(d, r$, $\left.R, L, J_{1}, J_{2}, E_{1}, E_{2}\right)$ を最適化すれば，最大回転角速 度 $\omega_{\max }$ および最大出力 $P_{\text {max }}$ が大きくなり, SMA エンジ ンを高出力化することができる.

4.2 シミュレーションによる検討＼cjkstart理論式(1), (2) に基づき, 最大回転角速度 $\omega_{\max }$ および最大出力 $P_{\text {max }}$ の 最適化, SMA エンジンの高出力化の方向性がわかった ので, $\mathrm{SMA}$ エンジンの外形的な諸量 $\left(d, r, R, L, J_{1}\right.$, $\left.J_{2}, E_{1}, E_{2}\right)$ が SMA エンジンの高出力化にどのように作 用するかシミュレーションを行った. シミュレーショ ン結果を図 2〜図 15に示寸. 先ず回転角速度 $\omega_{\max }-d$, 出力 $P_{\max }-d$ の関係を示す。

図 2, 図3より, SMA エンジンの回転角速度 $\omega_{\max }$, 出力 $P_{\max }$ は, SMA ベルトの直径 $d$ に非常に強く依存す 


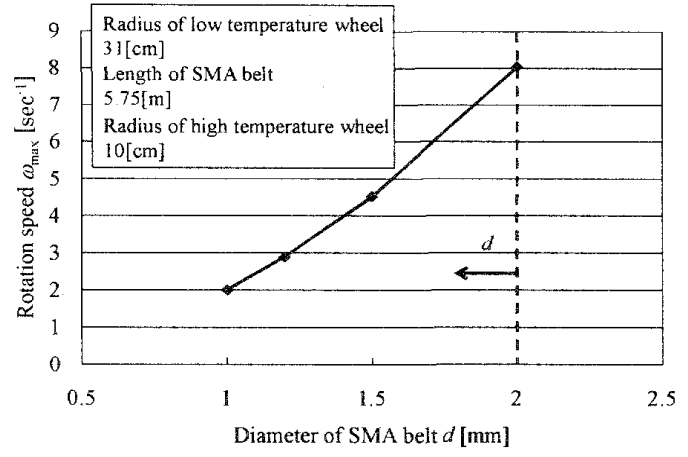

Fig. 2 Relation between $\omega_{\max }$ and $d$

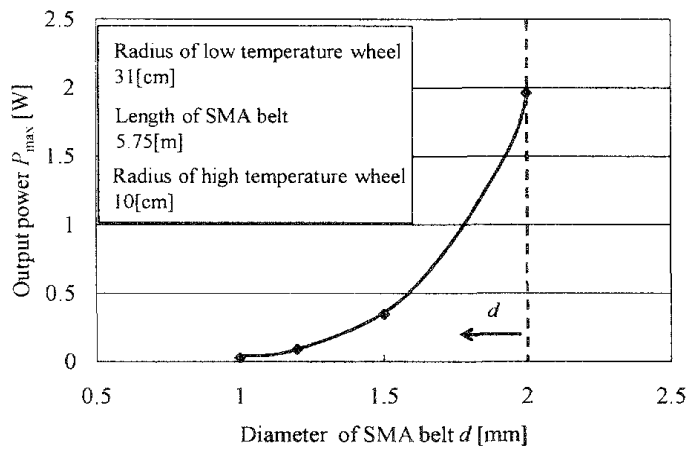

Fig. 3 Relation between $P_{\max }$ and $d$

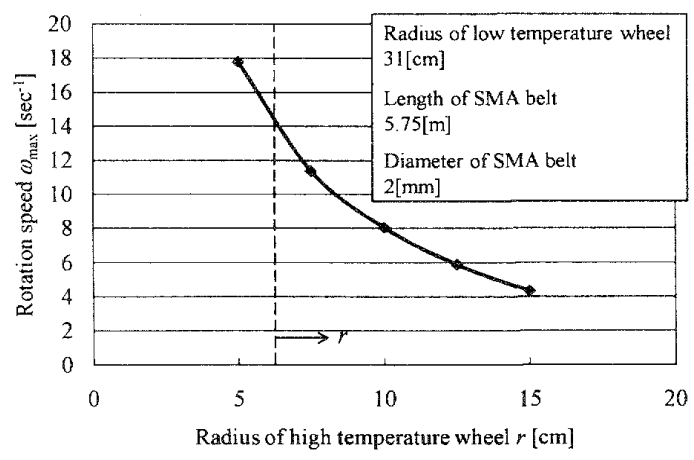

Fig. 4 Relation between $\omega_{\max }$ and $r$

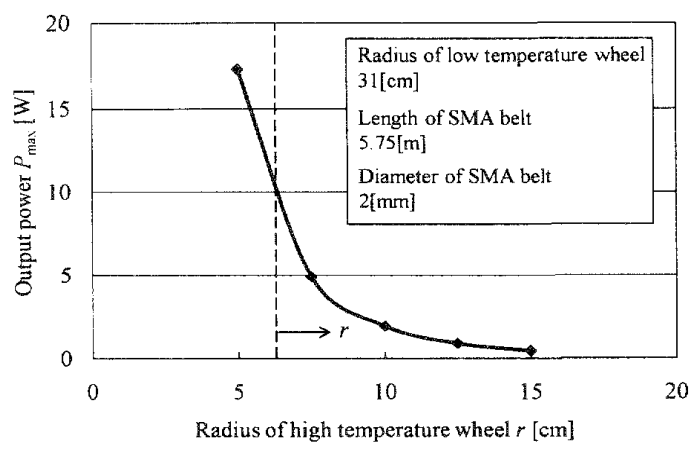

Fig. 5 Relation between $P_{\max }$ and $r$
ることがわかる。図2，図3より明らかなように， 回転角速度 $\omega_{\max }$ は $\mathrm{SMA}$ ベルトの直径 $d$ の 2 乗に比例し, 出力 $P_{\max }$ は SMA ベルトの淔径 $d$ の 6 乗に比例して増 大することがわかる. 本シミュレーション結果より SMA エンジンの高出力化の為には SMA ベルトの直径 $d$ を太くすればよいことがわかるが，現在入手可能な Ti-Ni 系 SMA ベルトの最大直径は $2 \mathrm{~mm}$ である。した がってこれ以降のシミェレーションでは現時点での 現実的な最大值 $d=2 \mathrm{~mm}$ とする.

図 4, 図 5 より, SMA エンジンの回転角速度 $\omega_{\max }$, 出力 $P_{\text {max }}$ は高温輪の半径 $r$ に強く依存し, SMA エンジ ンの高出力化の為には高温輪の半径 $r$ を小さくした方 がよいことがわかる。しかし，高温輪の半径 $r$ には下 限值がある. SMA ベルトのひずみを $1.5 \%$ 程度以下に する必要があり， $\varepsilon=d / 2 r<1.5 \%$ （必要条件）より，高 温輪の半径 $r$ は $6.7 \mathrm{~cm}$ 以上とする必要がある.

図 6, 図 7 より, 低温輪 $D$ 半径 $R>20 \mathrm{~cm}$ において, SMA エンジンの回転角速度 $\omega_{\max }$ は低温輪の半径 $R$ に ほぼ逆比例し, SMA エンジンの出力 $P_{\text {max }}$ は低温輸の半 径 $R$ にはあまり依存せず，低温輪の半径 $R$ を $20 \mathrm{~cm}$ か ら $40 \mathrm{~cm}$ に2 倍にしても出力は $15 \%$ 程度しか変化しな いことがわかった。また，网7から低温輪の半径 $R \leqq$ $20 \mathrm{~cm}$ では出力 $P_{\max }$ が急減することが明らかになった。 したがって，低温輪の半径 $R$ は従来加実験装置に使

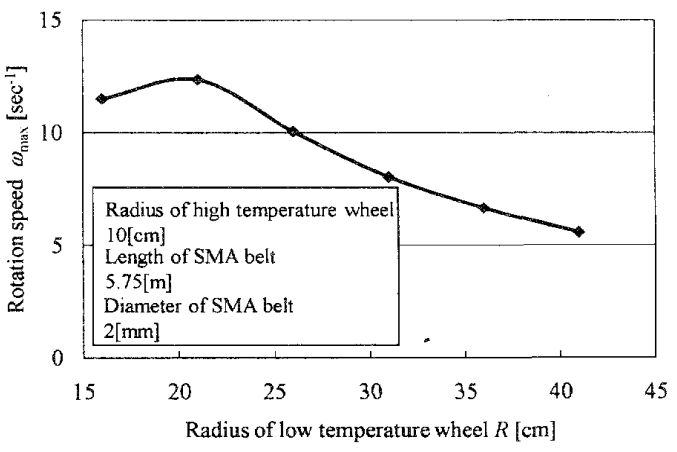

Fig. 6 Relation between $\omega_{\max }$ and $R$

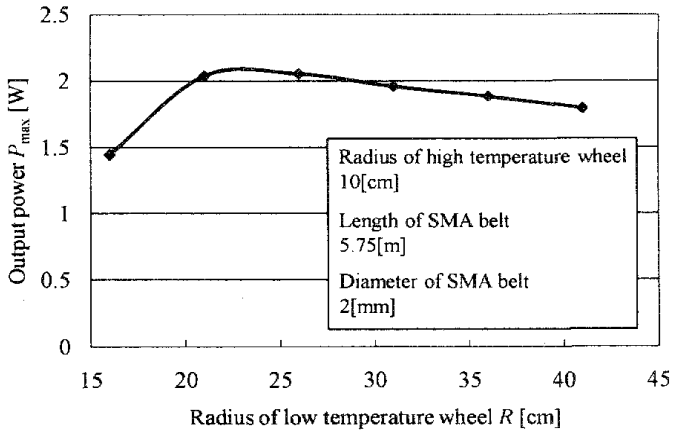

Fig. 7 Relation between $P_{\max }$ and $R$ 


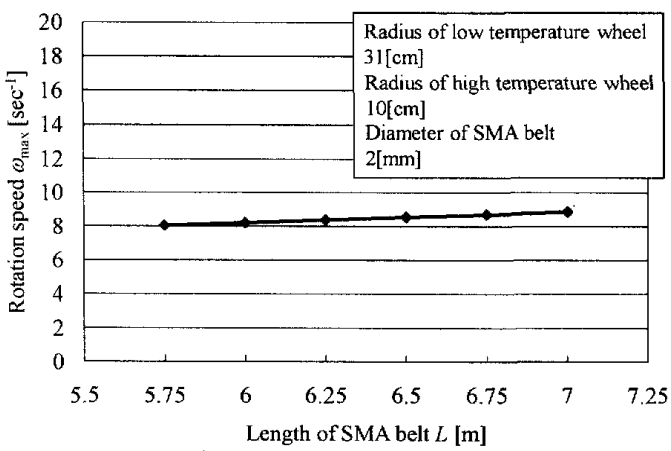

Fig. 8 Relation between $\omega_{\max }$ and $L$

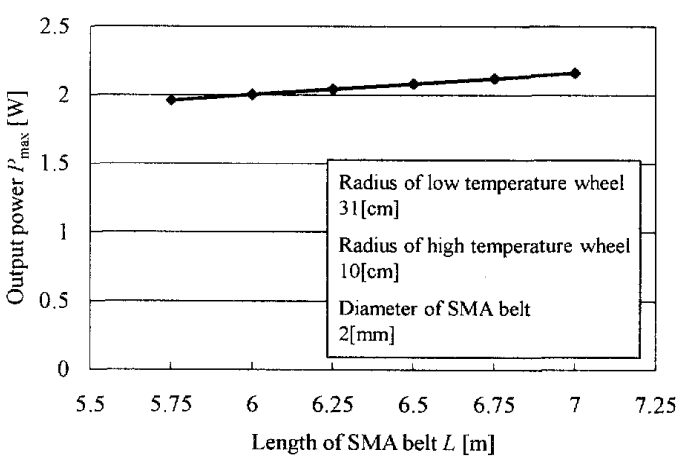

Fig. 9 Relation between $P_{\max }$ and $L$

用してきた市販の 26 インチ自転車の車輪を用いるこ ととし，以降のシミュレーションでは $R=31 \mathrm{~cm}$ とする. また図 8, 図 9 より, SMA エンジンの回転角速度 $\omega_{\max }$, 出力 $P_{\max }$ はSMA ベルトの長さ $L$ に対して単調增加す るが，それほど強く依存しないことがわかった。した がって，以降のシミュレーションでは, SMAベルトの 長さ $L$ は実験室の天井高さより実験装置の高さが制限 される最大長さとして $L=5.75 \mathrm{~m}$ とする.

高出力化の(5)番目の方法として慣性モーメント $J_{1}$, $J_{2}$ を小さくすれば良いことが推測される，具体的には 高温輪および低温輪を肉抜きすると同時に，軽い材料 を選べばよいことがわかる，そこで，車輪の材質とし て FRP(比重 1.6), アルミニウム Al(比重 2.7), 鉄 Fe(比 重 7.8), 銅 $\mathrm{Cu}$ (比重 8.9)の 4 種類を考え, 高温輪の比重 をパラメータとして，低温輪の材料密度を変化させた 場合の SMA エンジンの回転角速度 $\omega_{\max }$, 出力 $P_{\max }$ がど のように変化するかシミュレーションを行った. 図 10, 図 11 に示寸シミュレーション結果から明らかなよう に, 高温輪の材質を一番軽い FRP(比重 1.6)加一番重 い銅 $\mathrm{Cu}\left(\right.$ 比重 8.9)まで変化させても回転角速度 $\omega_{\max }$, 出 力 $P_{\max }$ は最大でも $10 \%$ 程度しか変化しない, 一方, 図 10 , 図 11 の横軸，すなわち低温輪の材質を一番重い銅 $\mathrm{Cu}$ (比重 8.9)から一番軽いFRP(比重 1.6)まで変化させる 之, 回転角速度 $\omega_{\max }$ および出力 $P_{\text {max }}$ は 2 倍以上増加す

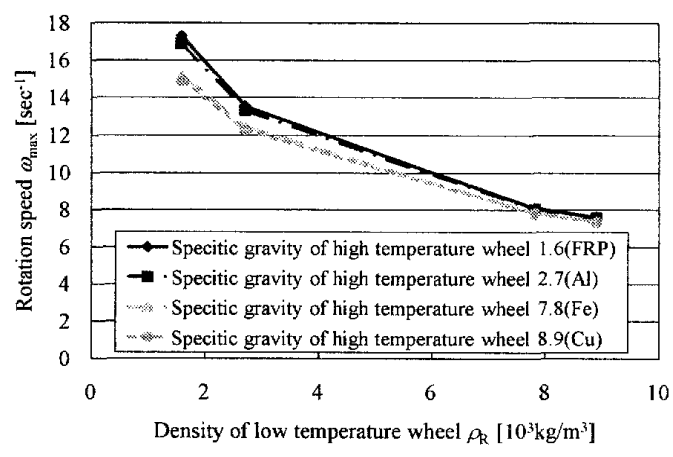

Fig. 10 Relation between $\omega_{\max }$ and $\rho_{\mathrm{R}}$

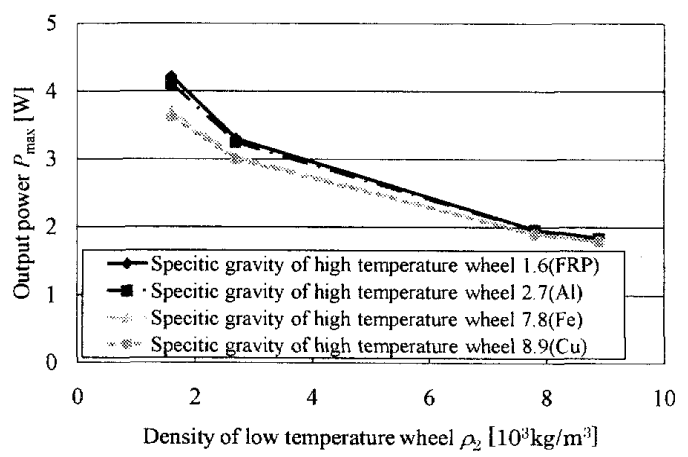

Fig. 11 Relation between $P_{\max }$ and $\rho_{\mathrm{R}}$

ることがわかった，直径の小さい高温輪を軽くしても 高出力化にはあまり寄与しないこと，および高温輪は 熱湯に浸けることを考慮して, 今後,一番軽い金属製, すなわちアルミニウム製とすることにする。一方，低 温輪はアルミニウム製あるいはFRP製の車輪とすれば, 出力は 2 倍になることがわかったが，現時点では人手 しやすい鉄あるいはステンレス製の自転車の車輪とし， 将来的にはアルミニウム製あるいはFRP製の車輪に取 り換える方針とする.

図 12〜図 15 より, SMA エンジンの回転角速度 $\omega_{\max }$, 出力 $P_{\max }$ は SMA ベルトのヤング率の高温時と低温時 の差 $E_{1}-E_{2}$ を大きくした方がよいことがわかる. 高温 時のヤング率 $E_{1}$ が 80GPa から 120GPaに 1.5 倍になれ ば出力 $P_{\text {max }}$ は3 倍になることがわかる (図 13 参照)。 一方，低温時のヤング率 $E_{2}$ が $40 \mathrm{GPa}$ から 20GPa に半 減すると, 出力 $P_{\max }$ は 2 倍になることがわかる（図 15 参照) ．以上のシミュレーションの結果, SMA エンジ ンの高出力化の為には SMA ベルトのヤング率の差 $E_{1}$ 一E $E_{2}$ 大きくすればよいことが確認できた。しかし， $\mathrm{SMA}$ ベルトのヤング率の差 $E_{1}-E_{2}$ はSMAベルトの製 造方法に強く依存し簡単には変えられない物性值であ る.したがって，以降の高出力化の検討では，SMA べ ルトのヤング率は $E_{1}=80 \mathrm{GPa}, E_{2}=40 \mathrm{GPa}$ に固定して検 討を進めることとする. 


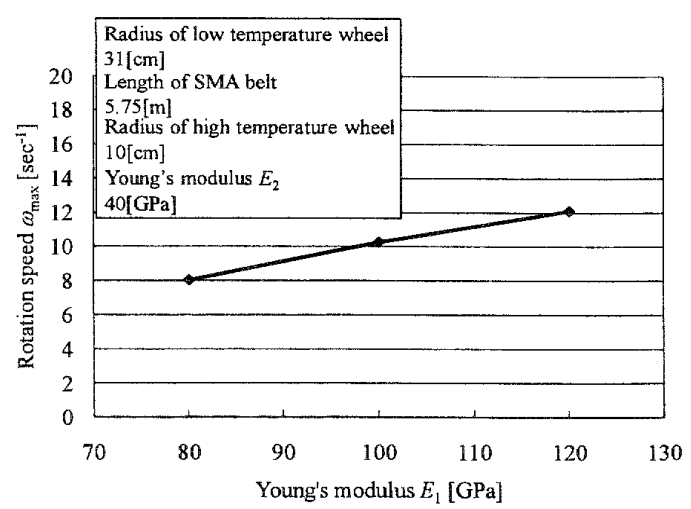

Fig. 12 Relation between $\omega_{\max }$ and $E_{1}$

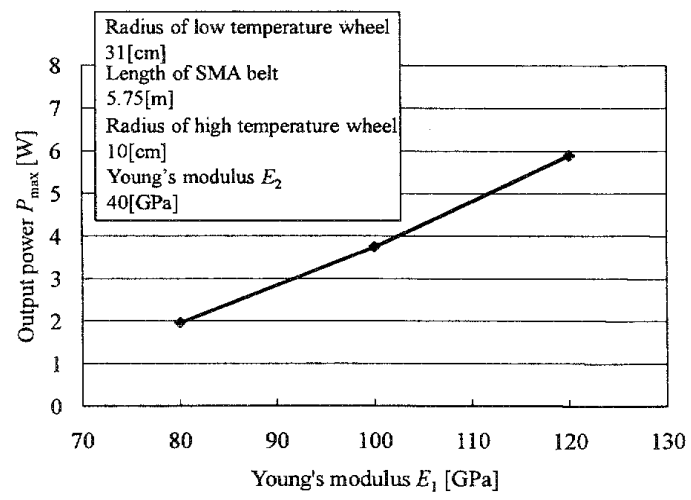

Fig. 13 Relation between $P_{\max }$ and $E_{1}$

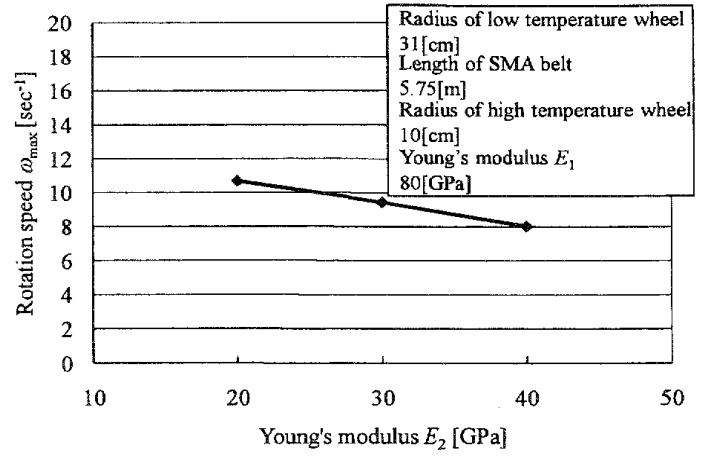

Fig. 14 Relation between $\omega_{\max }$ and $E_{2}$

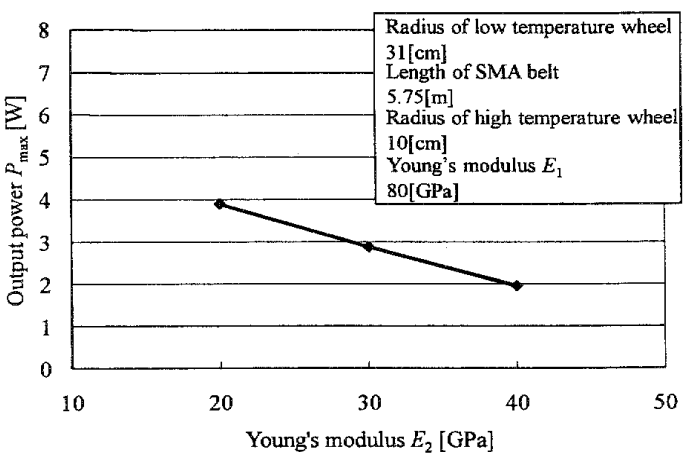

Fig. 15 Relation between $P_{\max }$ and $E_{2}$
以上, シミュレーションの結果, SMA エンジンの高 出力化の為には, SMA ベルトの直径 $d$ を太すること が最も有効であることがわかった，そこで，SMA ベル トの直径 $d$ に着目した実験を行い，シミュレーション 結果の妥当性を検証する.

\section{SMA ベルトの太さに関する实験}

5.1 予借実験（高温輸の半径 $r$ 取適化）導出し た理論式に基づいたシミュレーション結果より，高温 輪の半径 $r$ はSMAベルトのひずみにより制約される最 小半径が存在すると考えられることから，最大回転角 速度 $\omega_{\max }$ が得られる最適な高温輪の半径 $r$ を決定する 実験を行った，低温輪の半径を $R=31 \mathrm{~cm}$ と固定し，高 温輪の半径を $r=5 \mathrm{~cm}, 7.5 \mathrm{~cm}, 10 \mathrm{~cm}, 12.5 \mathrm{~cm}, 15 \mathrm{~cm}$ と 変化させ回転角速度実験を行った. 図 16 から明らかな ように, 高温輪の半径 $r=10 \mathrm{~cm}$ のとき, 最大回転角速 度 $\omega_{\max }$ の最大值が得られた，図 4, 図 5 に示すシミュ レーション結果より明らかなように，高温輪の半径 $r$ を減少させると, SMA エンジンの回転角速度 $\omega_{\max }$, 出 力 $P_{\max }$ は急激に増大し, SMA エンジンの高出力化に極 めて有効であることがわかる。しかし，高温輪の半径 $r$ に関しては前述のように SMA ベルトのひずみとわら 制約される下限值がある. SMA ベルトの弾性限界より， ひずみ $\varepsilon=d / 2 r<1.5 \%$ の条件を満たす必要があり，高温 輸の半径 $r$ は $r>6.7 \mathrm{~cm}$ でなければならない!さらに, SMA ベルトが高温輪に上手く巻き付き，高温輸を効率 良く踣る為には，図 17 に示す実験結果から明らかなと おり，高温輪の半径 $r$ を $r 7.5 \mathrm{~cm}$ とする必要がある. 以上の制約条件方よび図 16 に示予備実験の結果を 満たす高温輪の半径 $r$ 最適值を $r=10 \mathrm{~cm}$ と決定した. これを基に大型実験装置を設計・製作した.

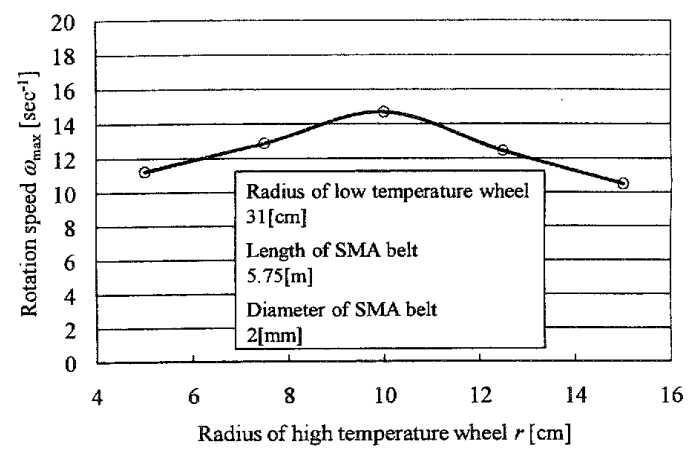

Fig. 16 Relation between $\omega_{\max }$ and $r$ 

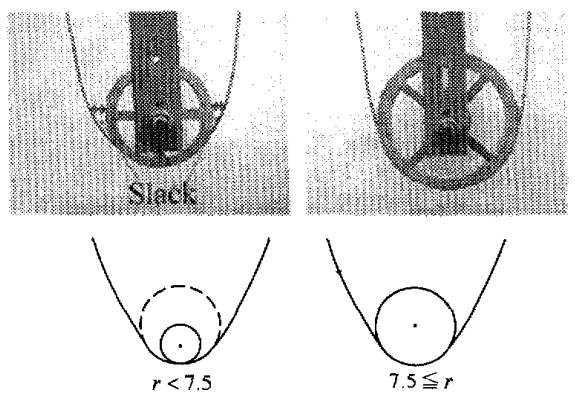

Fig. 17 Relation between $r$ and curvature radius of SMA belt $(d=2 \mathrm{~mm})$

5.2 実験装置シミュレーション結果およ び予備実験の結果より，SMA ベルトの長さを $L=5.75 \mathrm{~m}$, 低温輸の半径 $R=31 \mathrm{~cm}$, 高温輪の半径 $r=10 \mathrm{~cm}$ と固定し, SMA ベルトの直径を $d=1.2 \mathrm{~mm}$, $1.5 \mathrm{~mm}, 2 \mathrm{~mm}$ と変化させた場合の回転角速度 $\omega_{\max }$ と出力 $P_{\text {max }}$ の関係を実験的に調べた。 大型実験装 置全体の構成および寸法を図 18 に, 完成写真を図 19 に示す。

5.3 実験条件 SMA ベルトの直径 $d$ を変化せた 場合の SMA エンジンの出力特性実験（回転角速度 $\omega_{\max }$, 出力 $\left.P_{\max }\right)$ における実験条件として, SMA ベルトの直 径 $d$ を変化させた場合の点 2 および点 3 の温度とヤン グ率の関係を図 20 に示す. 図 20 に示す測定結果から 明かなように, SMA ベルトが高温輪に接触する点 20 温度 $t_{2}$ と低温輪に接触する点 3 の温度 $t_{3}$ に関しては, $t_{2} \gg t_{3}$ が成立しており，また点 2 におけるヤング率流 温域のヤング率 $E_{1}=80 \mathrm{GPa}$, 点 3 におけるヤング率は低 温域のヤング率 $E_{2}=40 \mathrm{GPa}$ の条件を満たしている.

\section{4 回転角速度 $\omega_{\max }$ に関する実験結果 SMA ベ} ルトの直径を $d=1.2 \mathrm{~mm}, 1.5 \mathrm{~mm}, 2 \mathrm{~mm}$ に変化させ, 無 負荷状態でそれぞれ回転角速度の測定を行う. SMA 工 ンジンの回転角速度 $\omega_{\max }$ は非接触光学式回転数計(ラ イン精機株式会社，TM-5010)で測定した. 実験結果を 図 22 に示す. SMA ベルトの直径 $d=1.2 \mathrm{~mm}$ のとき 6.53 $\mathrm{sec}^{-1}, d=1.5 \mathrm{~mm}$ のとき $7.21 \mathrm{sec}^{-1}, d=2 \mathrm{~mm}$ のとき $15.5 \mathrm{sec}^{-1}$ の回転角速度が得られた。

\section{5 最大出力 $\boldsymbol{P}_{\max }$ に関する実験結果 SMA}

ベルトの直径を $d=1.2 \mathrm{~mm}, 1.5 \mathrm{~mm}, 2 \mathrm{~mm}$ に変化さ せ, 回転角速度 $\omega$ とトルク $T$ を測定することにより 出力 $P_{\max }$ を求める. トルク $T$ はトルク変換器 (KYOWA 製: TP-20KCE)、動ひずみ計(KYOWA 製： DPM-601)、オシロスコープによって測定する．ト
ルク変換器の急荷側にヒステリシスブレーキ(小 倉クラッチ製：HB-10)を取り付け、ヒステリシス ブレーキの励磁電流を変化させることにより、負 荷の大きさを任意に制御し SMA エンジンのトル クを測定した(図21参照). 実験結果を図23に示す。 SMA ベルトの直径 $d=1.2 \mathrm{~mm}$ のとき $0.17 \mathrm{~W}$, $d=1.5 \mathrm{~mm}$ のとき $0.25 \mathrm{~W}, d=2 \mathrm{~mm}$ のとき $1.38 \mathrm{~W}$ の出 力が得られた。

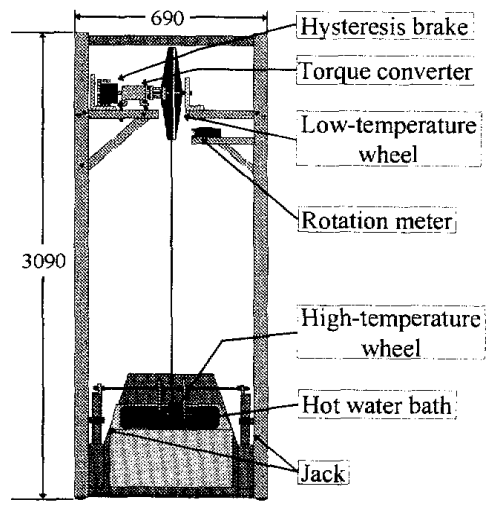

Fig. 18 Conceptual figure of high power experiment
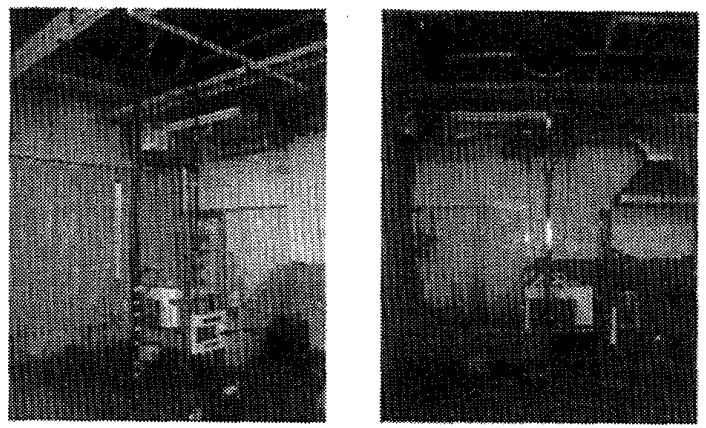

Fig. 19 Photograph of the assembled experiment equipment

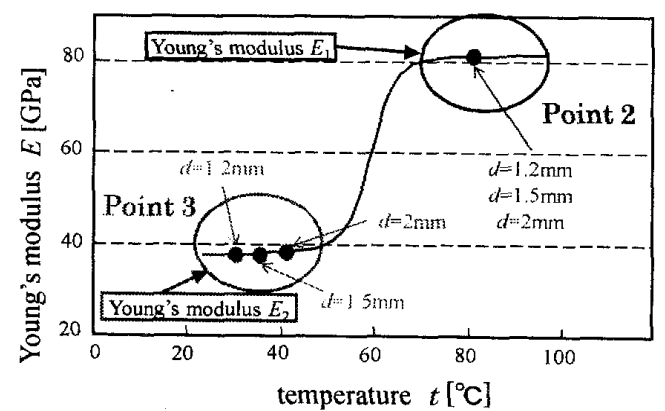

Fig. 20 Relation between Young's modulus and temperature 


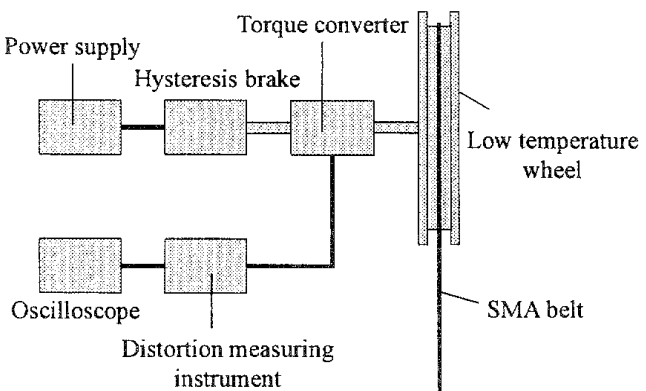

Fig. 21 Detailed drawing of torque measurement

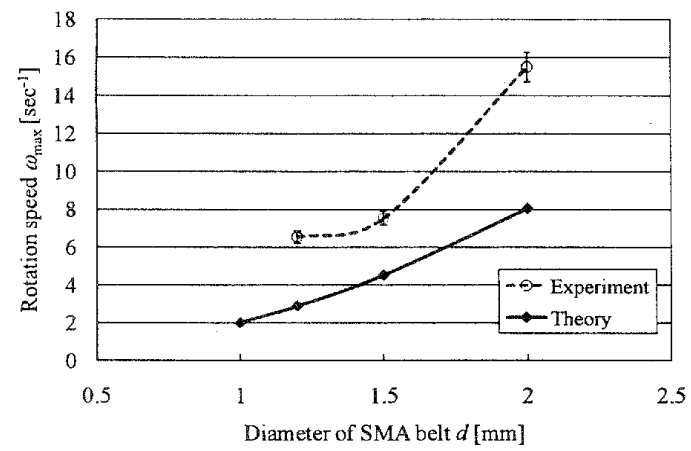

Fig. 22 Relation between $\omega_{\operatorname{lnax}}$ and $d$

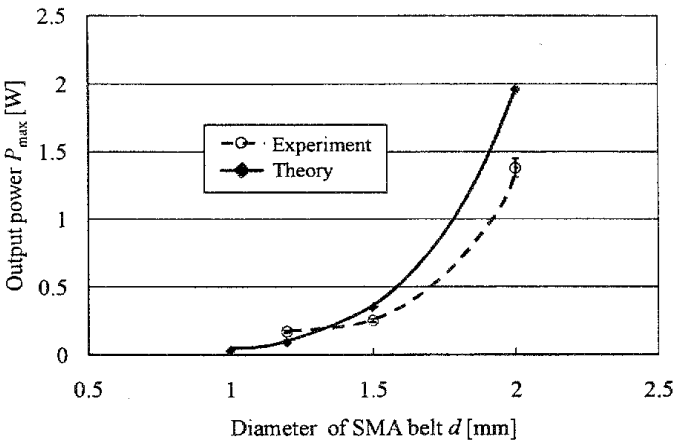

Fig. 23 Relation between $P_{\max }$ and $d$

\section{6. 考 察}

6.1 最大回転角速度 $\omega_{\max }$ に関する考察 最大回 転角速度 $\omega_{\max }$ の実験值は図 22 に示すとおり，傾向は理 論值とほぼ一致しているが，絶対值は理論值の 2 倍で ある．実験值と理論值の乘離についてはさらなる検討 が必要である。

6.2 最大出力 $\boldsymbol{P}_{\text {max }}$ に関する考察 最大出力 $P_{\text {max }}$ の実験值は図 23 に示寸とおり，傾向は理論值とよく一 致しており，絶対值は $d=1.2 \mathrm{~mm}$ でほぼ一致， $d=1.5 \mathrm{~mm}$ および $d=2 \mathrm{~mm}$ では理論值の $70 \%$ となっており，理論 值とよく一致している。傾向，絶対值ともに理論と実 験はよく一致しており，理論式(2)が SMA エンジンの 最大出力の予測に十分使えることがわかった。

\section{7. 結言}

本研究で得られた主な成果を以下にまとめて示す，

(1) SMA エンジンの無負荷回転角速度 $\omega_{\max }$, 最大出力 $P_{\text {max }}$ を予測する理論式を用いてシミュレーション を行い，高出力化の方向性を見出すことができた．

(2) SMA エンジンの出力は, SMA ベルトの直径 $d$ に 強く依存し(直径の6 乗に比例), SMA ベルトの直 径を製作可能な最大值 $(d=2 \mathrm{~mm})$ まで太くすること により高出力化が達成できることがわかった。

(3) SMA エンジンの出力は, 高温輪の半径 $r$ に強く依 存し, 高温輪の半径 $r$ を小さくするほど高い出力 が得られることが分かった. しかし, 高温輸の半 径 $r$ には下限值があり，その下限値は SMA ベル トのひずみ $\varepsilon=d / 2<1.5 \%$ (必要条件)で決定される ことがわかった。

(4) SMA エンジンの出力は、低温輪の半径 $R$ および SMA ベルトの長さ $L$ にはあまり依存しないこと がわかった。

(5) シミュレーションで明らかにした SMA エンジン の高出力化の方向性を実験的に検証するため, SMA ベルトの直径 $d$ を変化させた回転角速度害 験を行った結果, 実験值と理論值の傾向はシミュ レーション結果と比較的よく一致した。 しかし, 絶対值は理論值の約 2 倍となり,さらに検討が必 要であることがわかった.

（6） SMA ベルトの直径 $d$ を変化させた場合のSMA エ ンジンの出力実験を行った結果，実験值は傾向お よび絶対值ともにシミュレーション結果と非常 に良く一致し，理論式およびシミュレーション結 果の妥当性を間接的に実証することができた.

以上のとおり，シミュレーションおよび実験により， SMA エンジンの高出力化の方向性を明確にすること ができ, SMA エンジンを用いた新発電システムの実用 化に貢献することができた。

\section{辢 辞}

本研究の一部は（財）熱・電気エネルギー技術 財団からの研究助成金で行なわれました。また形 状記憶合金線材は大同特殊鋼株から提供して頂き ました。ここに記して感謝の意を表します。 
文

(1) W.S.Ginell, J.L.McNichols,Jr., and J.S.Cory, Nitinol Heat Engines for low-grade thermal energy conversion, Mechanical Engineering.Vol.101, No.5, (1979), pp.26-33

(2) H.Tobushi, J.R.Cahoon, Mechanical Analysis of a Solar-Powered Solid State Engine, Transactions of the Canadian Society of Mechanical Engineers, Vol.9, No.3, (1985), pp.137-141

(3) H.Iwanaga, H.Tobushi, and H.Ito, Basic Research on the Output Power Characteristic of Shape Memory Alloy Heat Engine (1 st Report) transaction of Japan Society of Mechanical Engineers, SeriesA, Vol.54, No.497, (1987), pp. $177-180$

(4) Y.Sato, N.Yoshida, Y.Tanabe and H.Fujita, Study on the Output Power Characteristic of a Shape Memory Alloy Engine, transaction of Japan Society of Mechanical Engineers, SeriesB, Vol.72, No.717, (2006-5), pp.227-233.

(5) Y.Sato and Y.Tanabe, Study on the Output Power Characteristic of a Shape Memory Alloy Engine(2nd Report), transaction of Japan Society of Mechanical Engineers, SeriesB, Vol.73, No.734, (2007-10), pp.166-172.

(6) Y.Sato,M.Kobayashi, Y.Kobayashi and M.Suzuki, Study on the Output Power Characteristics of the Shape Memory AlloyEngine(3rdReport), transaction of Japan Society of Mechanical Engineers, SeriesB, Vol.74, No.741, (2008-5),pp.162-168. 